\title{
Dawid Głownia
}

Dawid Głownia - doktorant w Instytucie Sztuk Audiowizualnych Uniwersytetu Jagiellońskiego. Jego zainteresowania badawcze obejmują historię kina japońskiego, głównie w jego relacji do szerszych procesów społeczno-politycznych, marginalne obszary światowego kina gatunków oraz socjologię (pop)kultury. Publikował m.in. w "Kulturze Popularnej”, "Silva laponicarum”, "Tematach z Szewskiej" i "Kulturze i Historii". Autor książki Sześć widoków na kinematografię japońskq: Kulturowe, społeczne, polityczne $i$ instytucjonalne konteksty kina. Wspóltwórca projektu Film-Kultura-Społeczeństwo. Członek Stowarzyszenia Badaczy Popkultury i Edukacji Popkulturowej „Trickster". 


\section{Polisemiczne potwory: Kaijū eiga jako nośnik treści spoleczno-politycznych. Casus Godzilli}

DOI: http://dx.doi.org/10.12775/LC.2014.034

„Filmy Ishirō Hondy, takie jak „Godzilla”, są przepełnione jego szczerym humanizmem i wrażliwą osobowością. Bardzo mi się to w nich podoba"'. Akira Kurosawa

\section{Od negacji po afirmację: Zachodnia recepcja kina tokusatsu}

rtykuł Terrence'a Rafferty'ego The Monster That Morphed Into a Metaphor, opublikowany na łamach „New York Timesa” z okazji 50. rocznicy premiery Godzilli (Gojira, 1954), stanowi świadectwo daleko posuniętych zmian, jakie w ciągu ostatnich dekad dokonały się w postrzeganiu zarówno samego Wielkiego G., jak i całego nurtu filmów o wielkich potworach czy japońskiej kultury popularnej w ogóle. Oto bowiem na łamach wpływowej gazety ukazuje się tekst, który opowieści o radioaktywnym monstrum siejącym zniszczenie w Tokio nie umiejscawia w obrębie zainteresowań cult afficionados, miłośników celuloidowych kuriozów, dla których sama dziwaczność filmu stanowi o jego wartości, ani nawet w ramach eskapistycznej rozrywki spod znaku egzotycznego science-fiction, lecz identyfikuje ją jako fe-

1 S. Galbraith IV, Japanese Cinema, Taschen, Cologne 2009, s. 89. 
Yokohama, luty 2011

(fot. S. Kołos)

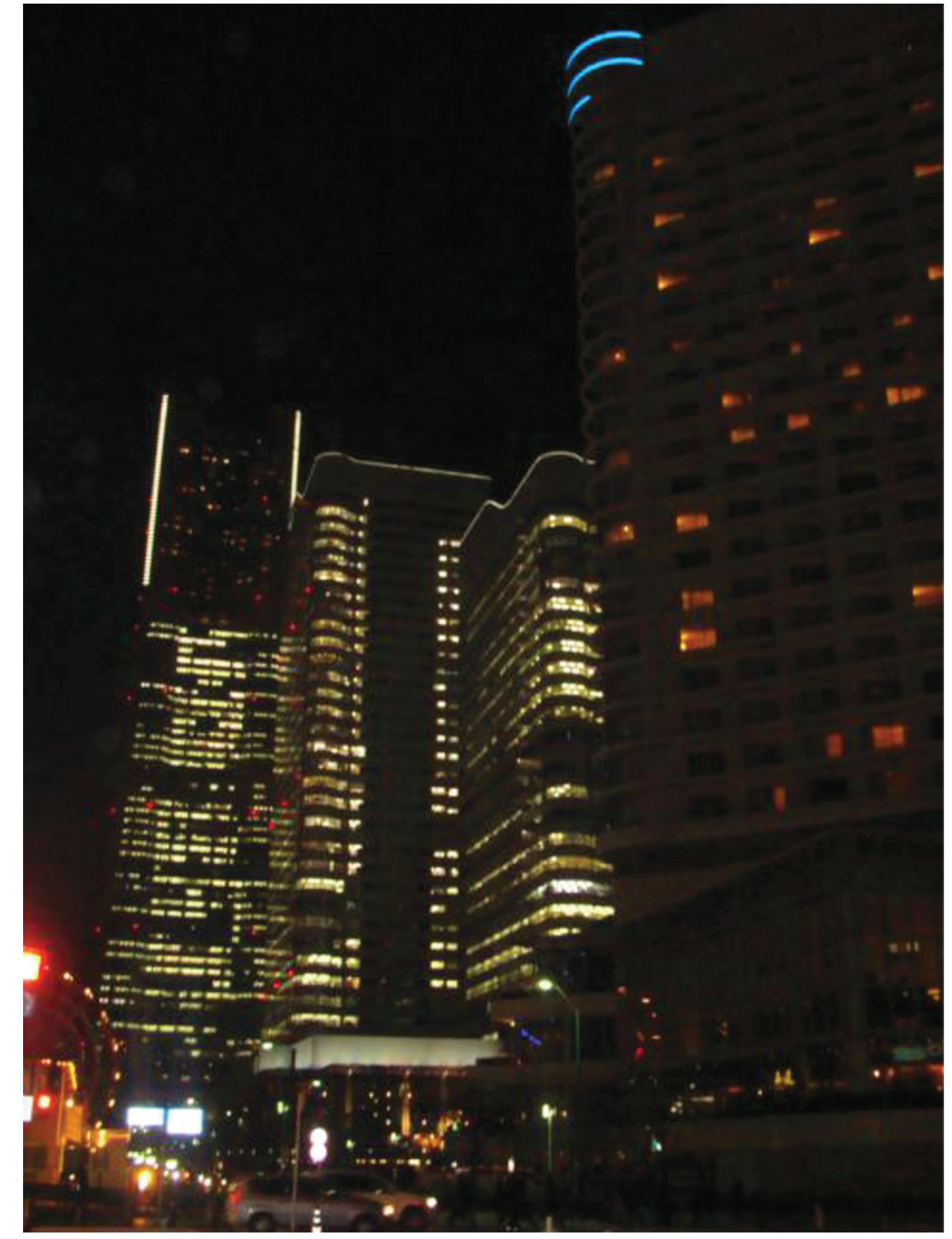


nomen kulturowy warty pogłębionej analizy. Na marginesie historii powstania filmu i jego eksportu do Stanów Zjednoczonych Rafferty przedstawił jego dominującą wykładnię, w myśl której Godzilla stanowi alegorię bomby atomowej. Wykładnię, podkreślmy, która wcześniej z trudem przedzierała się do świata głównego nurtu krytyki filmowej.

Paradoksalnie, mimo ogromnej popularności, jaką cieszyły się na Zachodzie japońskie filmy o wielkich potworach (kaijū eiga 怪獣映画 ${ }^{2}$ ), czy szerzej: japońskie filmy fantastyczne (tokusatsu eiga 特撮映画, dosł. „filmy z efektami specjalnymi”3), upłynąć musiały dekady, nim Godzilla i jego pobratymcy zagościli na gruncie „poważnego” dyskursu, tak publicystycznego, jak i akademickiego. Filmy przynależące do tego gatunku postrzegano jako „campowe, dziecinne spektakle, pozbawione jakiejkolwiek [wartości] artystycznej, [czy] intelektualnej i ideologicznej treści ${ }^{4}$, niewarte badawczego zainteresowania. Należy zauważyć, że podobny stosunek żywiono do całej japońskiej kultury popularnej. Jeszcze w drugiej połowie lat 90. XX wieku Mark Schelling pisał:

Wielu dziennikarzy piszących dla anglojęzycznych mediów w Japonii [...] zakłada, że fenomen kultury popularnej, atrakcyjnej dla masowej widowni, jest niegodny uwagi i można go bezpiecznie zignorować. Wolą więc odkrywać i promować artystów z obrzeży komercyjnego obiegu, niezależnie od tego, czy są tradycjonalistami, awangardzistami, czy po prostu autorami samymi wydającymi swe dzieła. W konsekwencji ich czytelnicy dowiadują się wiele o tancerzach butō i bębniarzach taiko, których widownia liczy się w setkach, a niemal nic o piosenkarzach popowych i zespołach, zapełniających całe stadionys.

Dopóki między „kulturą” a kulturą w wydaniu highbrow stawiany był znak równości, o rzeczowym omówieniu fenomenu filmów o wielkich potworach, wewnętrznego zróżnicowania i ewolucji formuly, przede wszystkim zaś różnic w zakresie recepcji wybranych tytułów między widownią japońską i zachodnią, nie mogło być mowy. Stąd też historycy kina japońskiego, kreślący narrację jego ekspansji na rynki światowe, zdawali się zapominać, że ta przebiegała dwutorowo. Równolegle bowiem do dzieł uznanych mistrzów ${ }^{6}$, wyświetlanych w limitowanej dystrybucji w kinach art-house'owych, do krajów zachodnich na masową skalę eksportowano filmy z nurtu kaijū eiga, które następnie przemontowywano i dubbingowano, by mogły trafić do szerszego grona odbiorców. Statystyczny Amerykanin miał więc większą szansę na zapoznanie się z Godzilla niż obejrzenie któregoś z samurajskich dramatów Akiry Kurosawy. Stuart Galbraith IV zauważa, że Godzilla to największa „gwiazda”, jaką wydała Japonia, a filmy o wielkich potworach stanowiły najważniejszy produkt eksportowy tamtejszego przemysłu filmowego, stając się dla wielu symbolem japońskiej

\footnotetext{
2 W dosłownym tłumaczeniu kaijū eiga oznacza "filmy o potworach", stąd też niektórzy autorzy skłonni są posługiwać się terminem daikaijū eiga 大怪獣映画, oznaczającym „filmy o wielkich potworach". Rozróżnienie między kaijū eiga a daikaijū eiga ma jednak sztuczny charakter, jako że niemal wszystkie kaijū to monstra o ogromnych gabarytach.

3 Produkcje te częściej określa się mianem tokusatsu 特撮. Termin tokusatsu eiga jest zazwyczaj stosowany w celu podkreślenia, że punkt odniesienia stanowią filmy pełnometrażowe, a nie seriale telewizyjne.

${ }^{4}$ W. M. Tsutsui, Introduction [w:] In Godzilla's Footsteps: Japanese Pop Culture Icons on the Global Stage, red. W. M. Tsutsui, New York 2006, s. 3.

${ }_{5}^{5}$ M. Schilling, The Encyclopedia of Japanese Pop Culture, New York 1997, s. 12.

${ }^{6}$ By wymienić tylko Rashōmon (1950) Akiry Kurosawy, Wrota piekieł (Jigokumon, 1953) Teinosuke Kinugasy czy 47 wiernych samurajów (Chushingura: Hana no maki yuki no maki, 1963) Hiroshiego Inagakiego.
} 
kinematografii ${ }^{7}$. Dość powiedzieć, że kiedy w 1985 roku przeprowadzono na zlecenie „New York Timesa" i CBS badania sondażowe na 1500 Amerykanach, w których poproszono o wskazanie najbardziej znanego Japończyka, pierwsze trzy miejsca zajęli: cesarz Hirohito, Bruce Lee i Godzilla ${ }^{8}$.

Wtargnięcie monstrów na obszary wcześniej im niedostępne - bronione bowiem z większą zaciekłością niż metropolie, które z łatwością obracały w pył - koresponduje z wyraźną tendencją do stopniowego otwierania się refleksji akademickiej na problematykę kultury popularnej, identyfikowanej - zwłaszcza na poziomie jej recepcji - jako istotna praktyka społeczna. Choć pierwszy głos nawołujący do poważnego potraktowania filmowych potworów pojawił się już w 1965 roku w tekście Susan Sontag zatytułowanym The Imagination of Disaster ${ }^{9}$, na prawdziwy przełom trzeba było czekać do 1987 roku, kiedy to na łamach „Cinema Journal” opublikowano artykul Godzilla and the Japanese Nightmare: When „Them!” Is U.S. autorstwa Chona Noriegi. W latach 90. grono akademików zainteresowanych problematyką społeczno-politycznego wymiaru filmów o Godzilli sukcesywnie się powiększało. Zwieńczeniem tych procesów było wydanie pracy zbiorowej In Godzilla's Footsteps: Japanese Pop Culture Icons on the Globar Stage, stanowiącej pokłosie konferencji pod tym samym tytułem, która odbyła się w 2004 roku na Uniwersytecie Stanowym Kansas.

$\mathrm{Z}$ biegiem lat swój stosunek do kaijū eiga zmienił nawet Donald Richie, inicjator zachodnich studiów nad kinematografią Kraju Kwitnącej Wiśni, którego negatywny stosunek do kina popularnego - przeciwstawianego przezeń kinu autorskiemu i niezależnemu - przez długi czas rzucał się cieniem na jego postrzeganie, legitymizując - na mocy autorytetu - zarówno jego miażdżącą krytykę, jak i kompletne ignorowanie. Jeszcze w 1990 roku, a więc po pierwszych publikacjach dostrzegających w nim coś więcej niż camp, Richie odmalowywał obraz japońskiego kina popularnego, jako „mrowia golizny, nastoletnich bohaterów, potworów science-fiction, kreskówek i filmów o słodkich zwierzaczkach"10. Choć w jego postrzeganiu kina popularnego trudno mówić o radykalnej wolcie i totalnym przewartościowaniu, to jednak przyznać trzeba, że obecnie skłonny jest on patrzeć na nie bardziej liberalnie, dostrzegając w nim głębsze treści. Piętnaście lat po tym, jak ironicznie wypowiadał się o bohaterach kaijū eiga, uznał, że gatunek ten zdolny jest ukazać Zeitgeist poszczególnych dekad: „Godzilla stał się czymś w rodzaju barometru nastrojów politycznych. Z punitywnej figury z przeszłości przekształcił się w przyjazną [istotę], w końcu zaś stanął w obronie swego kraju $[\ldots]$ nie tylko przed obcymi potworami, ale i machinacjami $[\ldots]$ ze strony USA i ZSSR"11.

Należy podkreślić, że akademickie zainteresowanie problematyką kaijū eiga jest nie tylko zjawiskiem względnie młodym, lecz także stosunkowo ograniczonym tematycznie, jako że badacze zwykle koncentrują się na pierwszej odsłonie cyklu o Godzilli, rzadko odnosząc się do jego kontynuacji czy filmów z udziałem innych monstrów. Decydującą rolę odgrywa w tym przypadku ewolucja - czy raczej: degradacja - serii, stopniowo odchodzącej od swych korzeni na rzecz widowisk przeznaczonych dla młodszej widowni. William

S. Galbraith IV, Japanese Cinema, s. 89.

8 W. M. Tsutsui, Godzilla on My Mind: Fifty Years of the King of the Monsters, New York 2004, s. 7.

9 S. Sontag, The Imagination of Disaster [w:] S. Sontag, Against Interpretation and Other Essays, New York 1979, s. 209-225.

10 D. Richie, Japanese Cinema: An Introduction, New York 1990, s. 80.

${ }^{11}$ Idem, A Hundred Years of Japanese Film. Revised and Updated Edition, Tokyo 2005, s. 178. 
M. Tsutsui zauważa, że „poza Japonią Godzilla pamiętany jest zwykle jako wielkooki slapstickowy super-bohater dla dzieci z filmów z lat 60., nie zaś jako poważny i zaangażowany politycznie potwór niosący przekaz, który zainicjował serię w latach $50 .{ }^{\prime 2}$. Trudno jednak zgodzić się z opinią Raffery'ego, wedle którego: „Metafora wyśliznęła się ze swych cum i wyruszyła w głąb morza, przekształcając się w tandetny statek rejsowy. [...] Nawet Japończycy od lat nie wierzą już w swą metaforę, dawno zamieniwszy swe rodzime potwory w sympatycznych zabawiaczy" ${ }^{13}$. W porównaniu do oryginału z 1954 roku jego kontynuacje cechują się mniejszym znaczeniowym nadbagażem i nie posiadają wyraźnie wyartykułowanej wymowy ideologicznej, nadal jednak pozostają cennym źródłem poznania japońskich nastrojów społecznych i niepokojów aktualnych w chwili ich premiery. Jak stwierdza Tsutsui:

Nawet w późniejszych dekadach, kiedy seria skierowana była do dużo młodszej i mniej świadomej politycznie grupy demograficznej, filmy o Godzilli nadal odnosity się do istotnych problemów, z którymi borykało się japońskie społeczeństwo: korporacyjnej korupcji, zanieczyszczenia, przemocy szkolnej, remilitaryzacji i odrodzenia japońskiego nacjonalizmu ${ }^{14}$.

Część ze społeczno-politycznych interpretacji kolejnych odsłon cyklu wydaje się zbyt daleko posunięta, niemniej jednak uzmysławiają one znaczeniowy potencjał tkwiący w formule. Steve Ryfle przytacza kilka z nich: Godzilla kontra Mothra (Mosura tai Gojira, 1964) stanowi krytykę nadmiernej komercjalizacji, Godzilla kontra Hedora (Gojira tai Hedora, 1971) ostrzega przed niebezpieczeństwem związanym z zanieczyszczeniem środowiska, z kolei Godzilla kontra Destruktor (Gojira tai Desutoroia, 1995) wyraża japoński niepokój przed utratą dominującej pozycji ekonomicznej w regionie w świetle zbliżającego się przejęcia Hongkongu przez Chiny ${ }^{15}$. Metafora bomby atomowej, choć faktycznie relatywnie szybko uległa wyczerpaniu, okazjonalnie powracała, jeżeli już nie na płaszczyźnie całego filmu, jak to było w przypadku rebootu z 1984 roku $^{16}$, to przynajmniej w jego wybranych aspektach. Należy jednak podkreślić, że przez kilka lat, jakie upłynęły od premiery Godzilli, wątek atomowy stanowił istotny element innych filmów przynależących do nurtu tokusatsu, zwłaszcza tych, które wyszły spod ręki Ishirō Hondy.

Źródeł rewaloryzacji Godzilli w ramach głównego nurtu krytyki filmowej, można doszukiwać się również i w tych dążnościach, które doprowadziły do reorientacji popkulturowej na polu akademickim, kluczową rolę odegrał jednak inny czynnik. Otóż przez dwadzieścia sześć lat krytycy filmowi pozbawieni byli możliwości zapoznania się z oryginalną wersją filmu, stąd też ich ocena opierała się na wrażeniach wyniesionych z seansu drastycznie okaleczonej amerykańskiej wersji. We wrześniu 1955 roku Edmund Goldman zaku-

12 W. M. Tsutsui, Introduction, s. 3-4.

13 T. Rafferty, The Monster That Turned Into a Metaphor, "New York Times" 04.052004, http://www.nytimes. com/2004/05/02/movies/film-the-monster-that-morphed-into-a-metaphor.html [stan na dzień: 10.04.2012].

${ }_{14}$ W. M. Tsutsui, Kaiju Eiga / Monster Movies, [w:] Directory of World Cinema: Japan, red. J. Berra, Bristol \& Chicago 2010, s. 208.

15 S. Ryfle, Japan's Favorite Mon-Star: The Unauthorized Biography of "The Big G", Toronto 1998, s. 14.

16 Filmy poświęcone Godzilli dzielą się na trzy serie: Shōwa (1954-1979), Heisei (1984-1995) i Millenium (1999-2004). Godzilla (Gojira, 1984) nie tylko stanowił nieformalny remake oryginalnego filmu, ale i otwierał nową serię, stąd też uzasadnione jest posługiwanie się w odniesieniu do niego pojęciem reboot. 
pił od amerykańskiego oddziału Tōhō ${ }^{17}$ prawa do dystrybucji Godzilli na terenie Stanów Zjednoczonych i Kanady. Wkrótce Goldman nawiązał współpracę z Haroldem Rossem i Richardem Kayem z Jewell Enterprises oraz Josephem E. Levinem z TransWorld Pictures. Jako że kontrakt umożliwiał właścicielom licencji wprowadzenie szeregu zmian, począwszy od dubbingu, przez przemontowanie filmu, skończywszy na usunięciu części scen, ci skwapliwie z tej możliwości skorzystali, dostosowując Godzillę do potrzeb lokalnej widowni. Amerykańska wersja filmu, zatytułowana Godzilla: Król potworów (Godzilla: King of the Monsters!), zadebiutowała na ekranach kin 27 kwietnia 1956 roku. Bardziej szczegółowy wykaz zmian, jakie na zlecenie swych mocodawców wprowadził do filmu Terry O. More zostanie przedstawiony w dalszej części artykułu. Na tym etapie wystarczy zaznaczyć, że do filmu wprowadzono około 20 minut materiału z udziałem Raymonda Burra wcielającego się w rolę amerykańskiego korespondenta, jednocześnie usuwając ponad trzydzieści minut oryginalnego materiału, skutecznie eliminując tym samym wiele odniesień do bomby atomowej i zmieniając wymowę filmu.

Godzilla: Król potworów został nieprzychylnie przyjęty przez amerykańskich krytyków. Choć na łamach części pism - m.in. „Variety” - doceniono zastosowane w nim efekty specjalne, większość recenzentów wypowiadała się w tonie Bosleya Crowthera z „New York Timesa", który określił go mianem niewiarygodnie kiepskiego filmu z kategorii tanich horrorów. Choć kolejne produkcje z nurtu kaijū eiga ściągały do kin tłumy, w „dobrym towarzystwie" mówić o nich nie wypadało. Sytuacja uległa zmianie w 1982 roku, kiedy w USA zaprezentowano oryginalną wersję filmu. Tym razem odzew krytyki był entuzjastyczny. Warto w tym miejscu przytoczyć opinie Carrie Rickey z „Village Voice”, która stwierdziła, że choć Godzilla jest tylko gumową miniaturką, problematyka, którą podejmuje jest globalna, oraz Howard Reicha z „The Chicago Tribune”, który określił film mianem niesamowitej metafory wojny nuklearnej i przypowieści o życiu i śmierci, uderzającej z siłą młota ${ }^{18}$.

Nim wartość artystyczna i intelektualna przynajmniej części tokusatsu została dostrzeżona przez akademików i profesjonalnych dziennikarzy, pogląd ten artykułowano w środowisku fandomu. Na łamach fanzinów takich, jak „Japanese Fantasy Film Journal” (wydawany w latach 1968-1983) i ich następców w rodzaju „G-FAN” (pismo założone w 1992 roku i ukazujące się do dziś) można było przeczytać artykuły: Godzilla i powojenna Japonia, Symbolika Godzilli czy Japonia, Godzilla i bomba atomowa. Choć kontrybutorzy tych pism często wpadali w sidła nadinterpretacji, widząc drugie dno w miejscach go pozbawionych ${ }^{19}$, należy im się uznanie, jako pionierom krytycznej refleksji nad społeczno-polityczną wymową japońskiego kina fantastycznego.

17 Tōhō był producentem i dystrybutorem serii filmów o Godzilli. Na fali popularności japońskich filmów na Zachodzie we wczesnych latach 50. firma założyła w Los Angeles swą placówkę. Filmy wytwórni prezentowano w La Brea Theater, kinie otwartym w 1926 roku przez wytwórnię Fox. W 1974 roku kino zamknięto. Obecnie mieści się w nim koreański kościół.

18 S. Galbraith IV, Japanese Science Fiction, Fantasy and Horror Films: A Critical Analysis of 103 Features Released in the United States, 1950-1992, Jefferson 1994, s. 13.

19 Wystarczy wspomnieć o dyskusjach poświęconych symbolice tytułowych bohaterów filmu Frankenstein kontra Baragon (Furankenshutain Tai Chitei Kaijū Baragon, 1966), w których Tom Miller dopatrywał się sojuszu japońsko-niemieckiego oraz Stanów Zjednoczonych, natomiast Sean Ledden kapitalistycznych gospodarek Japonii i Niemiec, przeżywających okres gwałtownego rozwoju pod ochroną amerykańskiego parasola nuklearnego oraz międzynarodowego komunizmu. 


\section{Interpretując Godzillę: Między kanonicznym odczytaniem a (re)produkcją znaczeń}

Fabuła Godzilli nie należy do skomplikowanych, wpisuje się bowiem w znany schemat monster movie. W wyniku testów nuklearnych przeprowadzanych na Oceanie Pacyficznym napromieniowane zostaje prehistoryczne monstrum, które przez miliony lat żyło w niszy ekologicznej na głębokich wodach w pobliżu wyspy Odo. Ataki, których dopuszcza się na kilka statków i wioskę rybacką, skłaniają władze do wysłania na Odo grupy badawczej pod przewodnictwem paleontologa, dr Yamane (Takashi Shimura). Na miejscu ekipa odkrywa, że teren został napromieniowany, a w chwilę później ich oczom ukazuje się potwór. Rząd podejmuje decyzję unicestwienia Godzilli, co spotyka się ze sprzeciwem Yamane, który uważa, że bestia powinna zostać zbadana, by dowiedzieć się, co sprawiło, że przeżyła tak silną dawkę promieniowania. Godzilla dwukrotnie sieje spustoszenie w Tokio, uzmysławiając wszystkim, że Japońskie Siły Samoobrony nie są w stanie uporać się z zagrożeniem. Jedyną nadzieją dla Japonii jest technologia „Niszczyciela Tlenu”, opracowana przez dr Serizawę (Akihiko Hirata). Ten jednak jest niechętny jej upublicznieniu, obawia się bowiem, że zostanie ona wykorzystana przez polityków jako broń masowego rażenia. Naukowiec daje się w końcu przekonać, niszczy jednak wszystkie notatki, a po unicestwieniu Godzilli popełnia samobójstwo, by jego wynalazek nie mógł już nigdy zostać użyty.

Owa prostota fabularna, połączona z towarzyszącym seansowi odczuciem, że w filmie tkwi więcej niż widać na pierwszy rzut oka, sprawia, że Godzilla podatny jest na szereg czasem komplementarnych, czasem przeciwstawnych interpretacji. Choć mutacja popromienna stanowiła popularny lejtmotyw kina science fiction lat 50. - by wymienić tylko Bestię $z$ głębokości 20.000 są̇̇ni (The Beast from 20,000 Fathoms, 1953), Potwora z głębi oceanu (Monster from the Ocean Floor, 1954), One! (Them!, 1954), To przyszło z głębin morza (It Came from Beneath the Sea, 1955), Atak potwornych krabów (Attack of the Crab Monsters, 1957) - Godzilla znacznie różni się od swych amerykańskich poprzedników i następców. O ile w większości z nich wątek atomowy pełnił jedynie funkcję MacGuffina inicjującego strukturę fabularną filmu, o tyle w Godzilli stanowił on jego centralny element oraz podstawę do szerzej zakrojonej refleksji nad bronią nuklearną. Co więcej, jego wymowa diametralnie odbiega od tej zawartej w Bestii z głębokości 20.000 sążni czy To przybyło z głębin morza, $\mathrm{w}$ których receptą na atomowe zagrożenie, symbolizowane przez potwora, jest zastosowanie silniejszej broni ${ }^{20}$. Godzilla tymczasem, miast legitymizować atomowy wyścig zbrojeń, stanowczo mu się sprzeciwia.

Dominująca wykładnia Godzilli nakazuje widzieć w tytułowym potworze symboliczną reprezentację bomby atomowej, zaś w całym filmie alegoryczną przestrogę przed niebezpieczeństwem potencjalnego konfliktu nuklearnego. Znaczeniowa niedookreśloność pew-

${ }^{20}$ W To przybyło z głębin morza gigantyczna ośmiornica zostaje unicestwiona za pomocą torpedy z głowicą nuklearną, natomiast w Bestii z głębokości 20.000 sążni prehistoryczne monstrum ginie od pocisku zawierającego izotop radioaktywny. 
nych aspektów filmu oraz niejednoznaczny charakter Godzilli, jawiącego się zarówno jako demoniczny opresor, jak i niewinna ofiara broni masowego rażenia, umożliwia jednak formułowanie mniej kanonicznych interpretacji. Analiza piśmiennictwa poświęconego debiutowi „Króla potworów” pozwala na wyróżnienie dwóch tendencji interpretacyjnych: uniwersalizującej i konkretyzującej. Pierwszą z nich prezentuje Steve Ryfle, który stwierdza:

Nie ulega wątpliwości, że producent [Tomoyuki] Tanaka i reżyser [Ishirō] Honda stworzyli potwora na obraz bomby, ale metafora jest uniwersalna. Piekielny gniew Godzilli reprezentuje więcej niż tylko jeden konkretny niepokój współczesności - jest ucieleśnieniem zniszczenia, katastrofy, anarchii i śmierci, którą człowiek ściąga na siebie, gdy nierozważnie odkrywa zakazane sekrety natury, sonduje przerażające granice technologii i nauki oraz $[\ldots]$ pozwala swej chciwości i żądzy władzy przerodzić się w wojnę ${ }^{21}$.

Wykładnia ta, mimo że odrywa film od kontekstu bomby atomowej, nie odbiega w znacznym stopniu od intencji twórców. Nie można powiedzieć jednak tego samego o części z odczytań zmierzających do konkretyzacji opowieści. Sceny ukazujące nieefektywność Japońskich Sił Samoobrony w walce z Godzillą bywają interpretowane jako symboliczna reprezentacja obaw związanych z niemożnością stawienia oporu potencjalnej inwazji, zwłaszcza ze strony bloku komunistycznego ${ }^{22}$. Z drugiej strony pojawiają się głosy, w myśl których Godzilla, jako element folkloru mieszkańców wyspy Odo, nie może być postrzegany jako zewnętrzny wróg, stąd też bardziej zasadne jest rozpatrywanie filmu w kategoriach metafory skutków wcześniejszej polityki imperialnej Japonii, która doprowadziła do odwetu Amerykanów i zniszczenia japońskich miast ${ }^{23}$. Najbardziej nieortodoksyjne interpretacje konkretyzujące prezentują komentatorzy japońscy. Zdaniem Tomayasu Kobayashiego fakt, że w żadnym filmie z cyklu Japończycy nie otrzymują wsparcia ze strony Stanów Zjednoczonych, stanowi jasny komunikat, iż w zakresie obrony własnego kraju Japończycy mogą liczyć wyłączne na siebie. Norio Akasaka natomiast widzi w Godzilli ucieleśnienie duchów japońskich żołnierzy, którzy zginęli podczas II wojny światowej, a Yosuo Nagayama przyrównuje monstrum do Saigō Takamoriego, w obu dopatrując się wroga nie ludu, lecz polityki władz ${ }^{24}$.

Najbardziej interesujące rozważania na temat symbolicznego wymiaru Godzilli wywodzą jego rodowód z prób uchwycenia, zdefiniowania i oswojenia powojennych traum społeczeństwa japońskiego, zarówno w ich skonkretyzowanym wymiarze, odnoszącym się do ataku atomowego na Hiroszimę i Nagasaki, jak i na bardziej ogólnej płaszczyźnie całokształtu doświadczenia wojennego i grozy potencjalnego konfliktu nuklearnego. Nurt ten zapoczątkował wspomniany już Chon Noriega, łączący problematykę powojennej traumy z napięciami zimnowojennymi i niepewnymi relacjami japońsko-amerykańskimi ${ }^{25}$. Rozwijając myśl Noriegi Susan Napier stwierdziła, że historia Godzilli - zwłaszcza przedstawione na ekranie sceny paniki i zniszczenia - może być odczytywana jako forma kulturowej terapii,

\footnotetext{
21 S. Ryfle, op. cit., s. 37.

22 R. B. Palmer, Gojira, [w:] International Dictionary of Films and Filmmakers, Volume 1: Films, red. T. Pendergast, S. Pendergast, New York 2000, s. 468.

${ }^{23}$ T. Rafferty, op. cit.

24 D. Kalat, A Critical History and Filmography of Toh's Godzilla Series, Jefferson 1997, s. 22-23.

${ }_{25}$ Ch. Noriega, Godzilla and the Japanese Nightmare: When "Them!" Is U.S., "Cinema Journal" 1987, vol. 27,
} no. 1, s. 63-77. 
umożliwiającej pokonanym Japończykom przepracowanie traum związanych z wojennymi bombardowaniami ${ }^{26}$. R. Barton Palmer zauważa:

Godzilla to ważny konstrukt japońskiej kultury popularnej, w którym donośnym echem odbijają się wątki charakterystyczne dla powojennych doświadczeń kraju. Wydaje się on potwierdzać teorie głoszone przez socjologów takich jak Siegfried Kracauer, w myśl których kino głównego nurtu, zwłaszcza w czasach głębokich społecznych kryzysów, przenosi na ekrany obawy przed katastrofą i nadzieje na wybawienie, które są głęboko zakorzenione w podświadomości podekscytowanej widowni ${ }^{27}$.

W nurcie analizy psychoanalitycznej sytuują się również rozważania Marka Andersona, odwołującego się do freudowskiego rozróżnienia żałoby i melancholii. O ile żałoba jest zwykle reakcją na utratę ukochanej osoby lub abstrakcji, która zajęła jej miejsce (ojczyzna, wolność, czy jakakolwiek inna idea), o tyle melancholia wiąże się z uczuciem wrogości oryginalnie odczuwanej względem innej osoby, ale zinternalizowanej i skierowanej na siebie. Melancholik żywi w kierunku tak siebie, jak i „innego” ambiwalentne uczucia miłości i nienawiści. Zdaniem Andersona trudno jest nie odczytywać Godzilli - przynajmniej częściowo - jako symptomu japońskiej melancholii narodowej. Badacz pyta:

Czy istnieją jakiekolwiek wątpliwości, że po serii zniszczeń i porażce doznanej z rąk Stanów Zjednoczonych, po tym jak coś, co miało być wojną o wyzwolenie, zostało zdefiniowane jako zbrodnia przeciw ludzkości, po tym jak japońscy żołnierze, którzy wcześniej przedstawiani byli jako wzór cnót, zostali oskarżenie o zbrodnie wojenne, japońskie uczucia względem Stanów Zjednoczonych i swoich własnych ofiar wojennych musiały składać się z ambiwalentnych uczuć zarówno miłości, jak i nienawiści $?^{28}$

„Przed wojną uczono nas, że Japończycy są przodującym narodem na świecie. Po wojnie musieliśmy zrewidować nasz sposób myślenia i odrodzić się na nowo"29 - stwierdził niegdyś Nagisa Oshima. „Dla mnie sprawą zasadniczą był sposób myślenia, który zaszczepiono mi od dziecka i załamanie się tej koncepcji świata po szoku, jakim stała się klęska Japonii w ostatniej wojnie"30 - wtórował mu Kirirō Urayama. Godzilla mogła więc służyć pytanie tylko: na ile zgodnie z intencjami twórców - jako podstawa kolejnej reinterpretacji losów XX-wiecznej Japonii. Takayuki Tatsumi stwierdza, że monstrum odegrało ważną rolę $\mathrm{w}$ „rekonstrukcji narodowej tożsamości poprzez uczynienie się ofiarami stawiającymi opór zewnętrznemu zagrożeniu"31.

${ }^{26}$ S. Napier, When Godzilla Speaks, [w:], In Godzilla's Footsteps: Japanese Pop Culture Icons on the Global Stage, red. W. M. Tsutsui, M. Ito, New York 2006, s. 10.

27 R. B. Palmer, op. cit., s. 468.

${ }_{28}$ M. Anderson, Mobilizing Gojira: Mourning Modernisty as Monstrosity, [w:] In Godzilla's Footsteps: Japanese Pop Culture Icons on the Global Stage, red. W. M. Tsutsui, M. Ito, New York 2006, s. 26-27.

${ }_{29}$ G. Sadoul, Credo "młodego kina” japońskiego - wywiad Goergesa Sadoula z czołowymi reprezentantami „nowego kina” japońskiego, „Kultura Filmowa” 1969, nr 8 (131), s. 34.

30 Ibidem, s. 30.

31 T. Tatsumi, Waiting for Godzilla: Chaotic Negotiations between Post-Orientalism and Hyper-Orientalism, [w:] Transactions, Transgressions, Transformations: American Culture in Western Europe and Japan, red. H. Fehrenbach, U. G. Poiger, New York 2000, s. 228. 
Krytycy doszukujący się kolejnych znaczeń w najdrobniejszych szczegółach filmu ${ }^{32}$ i poszukujący Świętego Grala jego „właściwej” (a więc: jednej, konkretnej i niepodważalnej) interpretacji popełniają podstawowy błąd. Nie biorą mianowicie pod uwagę faktu, że opowieść o atomowym monstrum nie jest utworem ani w pełni koherentnym, ani autorskim, stąd też przykładanie do niej art-house'owej miary jest bezzasadne. Godzilla to film zrealizowany relatywnie szybko - wstępny pomysł narodził się w marcu 1954 roku, w połowie kwietnia zatwierdzona została produkcja, 12 maja rozpoczęto prace nad zarysem historii, ukończonym pod koniec miesiąca, na początku czerwca podjęto trwające zaledwie trzy tygodnie prace nad scenariuszem, 5 lipca ogłoszono rozpoczęcie produkcji, na początku sierpnia przystąpiono do realizacji zdjęć, a finalny efekt przedsięwzięcia zaprezentowano podczas wewnętrznego pokazu wytwórni Tōhō, który odbył się 23 października - co sprawia, że w warstwie znaczeniowej nie każdy detal został doprecyzowany ${ }^{33}$. Co więcej, sami twórcy przy różnych okazjach przedstawiali odmienne interpretacje swego dzieła - choć ich wspólnym mianownikiem była bomba atomowa, istniały różnice w zakresie szczegółów.

„Król kaijü” to monstrum ze wszech miar polisemiczne, może więc symbolizować zarówno samą bombę, naturę mszczącą się na ludzkości za jej działania, zagrożenie konfliktem nuklearnym, jak i Japonię mszczącą się na swych obywatelach za drogę, na którą pchnęli ją w pierwszej połowie XX wieku. Nie stanowi to bynajmniej słabości filmu. Wręcz przeciwnie: świadczy o jego sile. W swym wymiarze historycznym Godzilla przynależy nie do porządku rozumu, lecz intuicji, tak na poziomie jego tworzenia, jak i pierwotnej recepcji. Film pozwalał na metaforyczne wyrażenie ambiwalentnych uczuć, które trudno było wyrazić w otwarty, pojęciowy sposób, oraz intuicyjne zbliżenie się do tego, co nie mogło zostać racjonalnie poznane i opisane.

\section{Trauma zbiorowa i jednostkowa: Przypadek Ishirō Hondy}

W większości analiz poświęconych Godzilli przyjmuje się perspektywę globalną, używa wielkich kwantyfikatorów, mówi o Japonii, Japończykach, Narodzie, Społeczeństwie. Problem w tym, że jakkolwiek Godzilla to stwór wyczulony na nastroje społeczne, nie został on powołany do życia ani przez (wszystkich) Japończyków, ani przez Naród, ani przez Społeczeństwo. Choć ma wielu ojców, wszystkich można wskazać z imienia i nazwiska. Byli to: producent Tomoyuki Tanaka, pisarz Shigeru Kayama, scenarzysta Takeo Murata, twórca efektów specjalnych Eiji Tsuburaya, kompozytor Akira Ifukube i reżyser Ishirō Honda. Warto więc zerwać z dominującą linią analityczną i przyjąć perspektywę jednostkową, konkretnie zaś przyjrzeć się temu, w jaki sposób w Godzilli odbijają się doświadczenia, obawy

32 Jak choćby wspominana już Norio Akasaka w scenie, w której po zniszczeniu Ginzy i budynku parlamentu Godzilla oszczędza Pałac Cesarski, co ma jakoby sugerować japońskie obywatelstwo potwora i szacunek, jakim darzy rodzinę cesarską, przeciwstawiany nienawiści do polityków, którzy pchnęli Japonie w odmęty wojny.

${ }^{33}$ Osobną kwestią jest to, że komentatorzy, zwłaszcza ci wywodzący się ze środowisk akademickich, skłonni są doszukiwać się głębokich struktur znaczeniowych w scenach czy aspektach filmu posiadających jedynie - by użyć terminologii Davida Bordwella - znaczenie referencyjne. 
i poglądy reżysera. Wybór Hondy na bohatera tej części artykułu nie jest ani arbitralny, ani przypadkowy, to on bowiem, mimo że do projektu dokooptowany został już kiedy istniał jego wstępny zarys, odegrał decydującą rolę w formowaniu finalnego kształtu filmu.

Kwestie wpływu Hondy na formę i wymowę filmu warto omówić tym bardziej, że w literaturze przedmiotu pokutują dwie błędne opinie na ten temat. Pierwsza z nich zakłada, że Godzilla była autorskim projektem Hondy. Samara Lea Allsop stwierdza na przykład, że „chcąc, by Godzilla oddziaływała na możliwie jak najszerszą widownię, Ishirō Honda odszukał najlepszego artystę od efektów specjalnych w Japonii, który podzielałby jego wizję filmu” ${ }^{4}$. Honda tymczasem nikogo nie „odszukał”, bowiem zarówno on, jak i Eiji Tsuburaya, o którym mowa w przytoczonym cytacie, zostali przydzieleni do realizacji filmu przez decydentów wytwórni. Pierwotnie zresztą Godzillę wyreżyserować miał Senkichi Taniguchi, jednak kiedy projekt uzyskał zielone światło, ten pracował już nad innym filmem ${ }^{35}$. Opinią biegunowo przeciwstawną, choć nie mniej błędną, jest kompletna deprecjacja osobistego wkładu Hondy zarówno w Godzillę, jak i w kolejne zrealizowanego przezeń filmy. Alexander Jacoby stwierdza, że w jego filmografii widoczne są socjologiczne i atomowe fascynacje, lecz te należy przypisać raczej scenariuszom niż reżyserii, stąd też Honda pamiętany jest bardziej za sprawą filmów, do których został przydzielony, niż osobistych inklinacji ${ }^{36}$. Tymczasem, wbrew opinii rzemieślnika na zlecenie, Honda - zwłaszcza na początku kariery - nie tylko potrafił odrzucać propozycje, które nie znajdowały jego uznania, ale również wywierał wpływ na kształt scenariuszy, wprowadzając do nich interesujące go wątki. Choć brał udział w pracach nad scenariuszami do wielu swoich filmów, rzadko uwzględniano to w czołówce, ponieważ Honda nie chciał przypisywać sobie zasług scenarzystów odpowiedzialnych za główną linię historii ${ }^{37}$. Niemniej jednak fakt, że tematyka atomowa obecna jest w 18 z 25 jego filmów fantastycznych ${ }^{38}$, nie może być uznany za dzieło przypadku.

Analiza Godzilli pod kątem biografii i światopoglądu Ishirō Hondy wiąże się z istotnym problemem, mianowicie nieuchronnym zacieraniem się linii demarkacyjnej oddzielającej perspektywę jednostkową od perspektywy globalnej. Należy bowiem pamiętać, że traumy filmowca były w równiej mierze osobiste, co powszechne, a jego doświadczenia były doświadczeniami szerokich mas społeczeństwa japońskiego. Fakt ten sytuuje dalsze rozważania w niejakiej opozycji do dominującego nurtu badań nad wątkami autobiograficznymi $\mathrm{w}$ dziele, te bowiem zwykle utożsamiają to, co jednostkowe, z tym, co unikalne, koncentrując się na tych doświadczeniach z życia autora, których nie podzielali jego współcześni.

$\mathrm{W}$ terminologii psychoanalitycznej trauma definiowana jest jako stan gwałtownego szoku, przerażenia i poczucia niebezpieczeństwa, w którym znajduje się podmiot pod wpływem określonego wydarzenia z przeszłości. Nie potrafi on opanować i przepracować lęków związanych z wydarzeniem traumatycznym, jako że to trudno mu je opisać i wyrazić w formie, która mogłaby przynieść ukojenie ${ }^{39}$. Społeczeństwo japońskie w krótkim czasie dostarczyło dwóch wydarzeń traumatycznych: ataku atomowego na Hiroszimę i Nagasaki z 6

${ }^{34}$ S. L. Allsop, Gojira / Godzilla, [w:] J. Bowyer, J. Choi, The Cinema of Japan and Korea, London, New York 2004, s. 63.

35 S. Ryfle, op. cit., s. 37.

${ }^{36}$ A. Jacoby, A Critical Handbook of Japanese Film Directors: From the Silent Era to the Present Day, Berkeley 2008 , s. 49.

${ }_{37}$ P. H. Brothers, Mushroom Clouds and Mushroom Men: The Fantastic Cinema of Ishiro Honda, Bloomington 2009, s. 11.

38 Ibidem, s. 8.

${ }^{39}$ K. Loska, Poetyka filmu japońskiego, t. 1, Kraków 2009, s. 349-350. 
i 9 sierpnia 1945 roku oraz bezwarunkowej kapitulacji zapowiedzianej 15 sierpnia w bezprecedensowym orędziu radiowym cesarza Hirohito, a podpisanej 2 września na pokładzie pancernika USS Missouri. Dla wielu Japończyków doświadczeniem traumatycznym była sama wojna. Dotyczyło to zarówno żołnierzy przelewających krew na froncie, represjonowanych dysydentów, jak i cywili, żyjących w strachu przed kolejnymi nalotami. „Nigdy nie uważałem tej wojny za świętą, chociażby z tego powodu, że wiązała się ona z represjami dokonanymi na mojej rodzinie [...], chciałem więc, by skończyła się jak najprędzej”"40 - wspominał po latach reżyser filmowy Susumu Hani. Choć część Japończyków wieść o kapitulacji przyjęła z radością, na każdym z nich wojna zostawiła swoje ślady.

Na początku 1954 roku doszło do incydentu, który choć trudno uznać go za wydarzenie traumatyczne per se, otworzył niezabliźnione rany społeczeństwa japońskiego i dał impuls do fali protestów antyatomowych. Rankiem 1 marca Amerykanie zdetonowali na wodach atolu Bikini bombę wodorową o sile 15 megaton, a więc 1000 razy silniejszą niż Little Boy zrzucony na Hiroszimę. Operacja Castle Bravo miała być rutynowym testem, jednak opad radioaktywny rozniósł się na obszar 7000 mil kwadratowych, docierając do kilku zamieszkałych wysp. W zasięgu chmury radioaktywnej znalazł się „Szczęśliwy smok nr 5” (Dago Fukuryū Maru), japoński statek do połowu tuńczyka. Po przybyciu do portu Yaizu załoga została hospitalizowana, a przeprowadzone na niej testy wykazały objawy choroby popromiennej. Pierwszą z sześciu ofiar incydentu był Aikichi Kuboyama, operator radiowy statku, który zmarł 23 września 1954 roku na białaczkę. Artykuł o tragedii pojawił się 16 marca na łamach „Yomiuri Shinbun”. Przez Japonie przeszła fala niepokojów społecznych. Zorganizowano m.in. bojkot tuńczyka oraz narodowy zbiór podpisów na petycji przeciw testom nuklearnym, którą do sierpnia 1955 roku podpisało ponad 30 milionów osób.

Godzilla jest dzieckiem kalkulacji, miłości do kina i strachu przed bombą atomową. Po tym, jak nie doszła do skutku planowana przez niego wojenna koprodukcja japońsko-indonezyjska, Tomoyoki Tanaka znalazł się pod silną presją, by szybko wymyślić dla Tōhō inny hit frekwencyjny. Jako że dwa lata wcześniej z powodzeniem wyświetlano w Japonii King Konga (1933), a w 1953 roku przebojem komercyjnym okazała się Bestia z głębokości 20,000 sążni, producent zwietrzył intratny interes w realizacji rodzimego monster movie ${ }^{41}$. Eiji Tsubaraya, będący wielkim fanem King Konga, którego po raz pierwszy zobaczył w latach 30., zapalił się do pomysłu, jako że od dawna marzył o realizacji podobnego filmu. Choć to Tanaka pomyślał o Godzilli jako alegorii bomby atomowej ${ }^{42}$, to jednak Ishirō Honda wyrwał potwora z objęć sztampy i nie pozwolił, by idiom fantastyki przytłoczył wymowę filmu.

Ishirō Honda urodził się 7 maja 1911 roku. Miłością do kina zapałał już w dzieciństwie, bardziej jednak od jego warstwy wizualnej, zafascynowała go filmowa gawęda, możliwość snucia przejmujących opowieści, co najbardziej uwidaczniało się w podziwie, jakim darzył benshi 弁士, narratorów filmowych. Po latach stwierdził: „Interesowali mnie oni bardziej niż to, co działo się na ekranie” ${ }^{\prime 3}$. W 1933 roku ukończył wydział filmowy Uniwersytetu

40 G. Sadoul, op. cit., s. 34 .

41 M. E. Matthews, Hostile Aliens, Hollywood and Today's News: 1950s Science Fiction Films and 9/11, New York 2007, s. 93.

42 Koronnymi argumentami, za pomocą których przekonał włodarzy wytwórni do inwestycji w ryzykowny pomysł, były dane dotyczące wyników kasowych King Konga i Bestii z głębokości 20.000 sq̨żni oraz plik artykułów poświęconych incydentowi z udziałem "Szczęśliwego smoka nr 5".

43 S. Ryfle, op. cit., s. 41. 
Japońskiego i rozpoczął pracę dla studia P.C.L., które później przekształciło się w Tōhō. Najcenniejsze doświadczenia zawodowe zdobył pod okiem Kajirō Yamamoto, podczas prac nad Koniem (Uma, 1941), Wojowniczymi sokołami Katō (Katō hayabusa sentōtai, 1944) i komediami z udziałem Enokena. Choć przymuszony przez władze realizował wojenne filmy propagandowe, z Wojna morska o Hawaje i Malaje (Hawai Marei oki kaisan, 1942) na czele, Yamamoto był znanym liberałem i nie ulega wątpliwości, że wywarł znaczny wpływ na światopogląd młodego Hondy. W 1937 roku przyszły twórca Godzilli poznał Akirę Kurosawę, z którym do śmierci łączyła go przyjaźń. Choć Kurosawa wkroczył na ścieżkę kina autorskiego, Honda zaś do końca kariery reżyserskiej poruszał się w obszarze kina gatunków, łączyły ich nie tylko bliskie osobiste więzi, ale i podobne spojrzenie na świat. Znamienne jest, że obaj - w odstępie roku - zrealizowali filmowe przestrogi antyatomowe, odnoszące się w sposób niebezpośredni do Hiroszimy i Nagasaki: Honda Godzillę, Kurosawa natomiast Żyję w strachu (Ikimono no kiroku, 1955).

W przeciwieństwie do Kurosawy Honda bezpośrednio doświadczył piekła wojny. W tyczniu 1935 roku został wcielony do armii, a w szesnaście miesięcy później wysłany do Mandżurii, udało mu się jednak powrócić do domu na kilka miesięcy przed wybuchem II wojny chińsko-japońskiej. Po raz drugi zmobilizowano go w latach 1939-1941. W 1944 roku ponownie wysłano go na front. Pod koniec wojny trafił do chińskiego obozu jenieckiego, gdzie spędził około pół roku. Po powrocie do Japonii w marcu 1946 roku udał się do Hiroszimy, by przyjrzeć się skali zniszczeń i oddać hołd zabitym.

Ze wspomnień krewnych i współpracowników wyłania się obraz człowieka poruszonego amerykańskim atakiem atomowym i doświadczonego przez wojnę. Znalazło to odbicie w jego najsłynniejszym dziele. „Godzilla jest filmem o potworach, ale reżyser [...] dodał do historii wiele warstw odnoszących się do grozy wojny" ${ }^{44}$ - wspominał Haruo Nakajima, aktor wcielający się w monstrum w latach 1954-1972. Potwierdził to sam Honda: „Większość warstwy wizualnej [filmu] zaczerpnąłem ze swoich doświadczeń wojennych" ${ }^{\text {"s }}$. Wiele czasu musiało jednak upłynąć, zanim był gotów opowiedzieć o swoich wojennych przeżyciach. Jak wspomina jego żona:

[Po premierze Niebieskiej perty (Aoi shinju, 1951)] zaproponowano mu pracę nad projektem poświęconych oddziałowi kamikaze. Pod wpływem lektury tomów materiałów źródłowych, uwzględniających testamenty zmarłych żołnierzy, oraz rozważań nad różnymi sprawami [...] doszedł do wniosku, że nie jest jeszcze gotów pisać na ten temat i odrzucił ofertę. Sądzę, że psychiczne okaleczenia, jakie wyniósł z ośmiu lat wojny, musiały być głębsze, niż ktokolwiek mógł to sobie wyobrazićc ${ }^{46}$.

Samara Lea Allsop stwierdza, że przyczyną wykorzystania formuły science-fiction jako platformy artykulacji treści odnoszących się do problematyki bomby atomowej była chęć utrzymania delikatnego status quo ukształtowanego po II wojnie światowej, które - mimo tego, że globalna opinia publiczna stała po ich stronie - uniemożliwiło Japończykom otwar-

44 H. Nakajima, Kaiju Conversations: An Interview with Godzilla, rozm. John Rocco Roberto, "Kaiju-Fan” 1/1999, online: http://www.historyvortex.org/Nakajimalnterview.html [stan na dzień: 10.04.2012].

45 S. Ryfle, op. cit., s. 42.

${ }^{46} \mathrm{~K}$. Honda, Memories of Ishiro Honda, online: http://www.japanesegiants.com/honda/messages/staff/ s0001_kimi_001.shtml [stan na dzień: 10.04.2012]. 
te krytyczne wypowiadanie się o amerykańskim ataku na Hiroszimę i Nagasaki ${ }^{47}$. Trudno jednak zgodzić się z tą tezą. Po pierwsze bowiem, antyatomowa wymowa filmu nie została przez jego twórców w żaden sposób zawoalowana, pada w nim nawet bezpośrednie odwołanie do Nagasaki. Po drugie, zanim jeszcze narodził się pomysł Godzilli, na ekranach japońskich kin wyświetlano już filmy poświęcone amerykańskiemu atakowi atomowemu: Dzwony Nagasaki (Nagasaki no kane, 1950) Hideo Ōby, Dzieci Hiroszimy (Genbaku no go, 1952) Kaneto Shindō, Nie zapomnę pieśni o Nagasaki (Nagasaki no uta wa wasureji) Tomotaki Tasaki czy Hiroszime (Hiroshima, 1953), Hideo Sekigawy. Opinia Allsop jest do utrzymania jedynie w odniesieniu do okresu amerykańskiej okupacji Japonii. Nie istniał wtedy, co prawda, oficjalny zakaz poruszania tematu Hiroszimy i Nagasaki, nie można było jednak przedstawiać bezpośredniego obrazu zniszczeń, zwłaszcza ofiar wśród ludności cywilnej, a sam fakt zrzucenia bomb musiał być osadzony w szerszym kontekście i przedstawiony jako konieczny krok umożliwiający zakończenie wojny ${ }^{48}$. Powodem, dla którego Honda zdecydował się opowiedzieć o swoich doświadczeniach i poglądach za pomocą fantastycznej alegorii, było raczej to, że filmy „racjonalne” nie zdały egzaminu, nie zdołały wszak przedstawić tego, co nieprzedstawialne, nie pomogły widzom w przepracowaniu ich traum i oswojeniu atomowego lęku.

Należy jednak podkreślić, że pomimo sięgnięcia po estetykę monster movie, Honda dołożył starań, by zapewnić filmowi maksymalną dawkę realizmu możliwą do osiągnięcia w ramach konwencji. Jak zauważa Steve Ryfle, reżyser podszedł do filmu bardziej jak do dramatu wojennego niż science-fiction, nadając mu - przynajmniej w wybranych aspektach - niemal dokumentalny charakter ${ }^{49}$. Podczas prac nad scenariuszem Takeo Murata i Ishirō Honda dokonali istotnych zmian w historii, którą stworzył Shigeru Kayama, popularny pisarz poruszający się w obszarach fantastyki i horroru. W oryginalnej koncepcji dr Yamane został przedstawiony jako ekscentryk w duchu bohaterów Edogawy Rampo, noszący czarną pelerynę i przyciemniane okulary, mieszkający w starym domu w stylu europejskim, który opuszczał tylko w nocy. Murata i Honda uznali, że skoro niezwykłe będzie samo tytułowe monstrum, naukowiec powinien być postacią realistyczną. Zmianie uległ również charakter Godzilli, który z campowego, acz działającego pod wpływem bardziej naturalnych instynktów drapieżnika, wychodzącego na ląd wyłącznie w celu zdobycia pożywienia, w późniejszych zaś partiach tekstu wykazującego zainteresowanie kobietami, przerodził się w istotę alegoryczną, niedookreślone zagrożenie, niszczące wszystko, co napotka na swej drodze, bez żadnych wyraźnych preferencji.

Quasi-dokumentalny charakter filmu objawia się zarówno w scenach, w których przedstawiono monstrum siejące zniszczenie na ulicach Tokio, jak i tych, w których ukazano przygotowania do odparcia ataku. Choć głównym nośnikiem warstwy znaczeniowej filmu są bohaterowie pierwszoplanowi - zwłaszcza dr Yamane i dr Serizawa - istotną rolę odgrywa w nim bohater zbiorowy - społeczeństwo japońskie, które stanęło w obliczu zewnętrznego zagrożenia. Honda odmalował na ekranie reakcje i nastroje, z jakimi spotykał się wśród ludności cywilnej podczas wojny. „Nagle wyłonienie się tego potwornego, niewymawialnego

47 S. L. Allsop, op. cit., s. 63.

48 K. Loska, op. cit., s. 252.

49 S. Ryfle, op. cit., s. 42. K. Honda, Memories of Ishiro Honda, online: http://www.japanesegiants.com/ honda/messages/staff/ s0001_kimi_001.shtml [stan na dzień: 10.04.2012]. S. L. Allsop, op. cit., s. 63. K. Loska, op. cit., s. 252. 
zagrożenia przywołało u japońskich widzów wspomnienia amerykańskich nalotów, które jeszcze kilka lat temu zmieniały ich miasta w płonące ruiny" 50 - rzecze Inuhiko Yomota. Skojarzenia te nie są w filmie implikowane, lecz - podobnie jak odniesienia do Nagasaki - wyrażane w sposób bezpośredni. „Mam nadzieję, że nie zaczną się znowu ewakuacje” - stwierdza jeden z mieszkańców Tokio. Jego nadzieje okazują się płonne. Po pierwszym ataku Godzilli Japońskie Siły Samoobrony ewakuują mieszkańców strefy przybrzeżnej na tereny wiejskie, powtarzając tym samym działania podejmowane kilka lat wcześniej przez Armię Cesarską. Realia Wojny na Pacyfiku przywołuje jeszcze jeden aspekt filmu, mianowicie sposób wykorzystania mass-mediów w procesach psychologicznej mobilizacji obywateli i organizacji ewakuacji. W Godzilli istotną rolę odkrywa nie tylko telewizja - która pojawiła się w Japonii w 1953 roku - ale również radio i prasa, skwapliwie wykorzystywane przez władze w okresie wojennym.

Świeże wspomnienia Hiroszimy i Nagasaki oraz lęki atomowe, ulegające intensyfikacji wraz z zaostrzaniem się konfliktu zimnowojennego, uderzyły społeczeństwo japońskie z nową siłą w chwili nagłośnienia incydentu z udziałem „Szczęśliwego Smoka nr 5”. Choć Tanaka wykorzystał społeczne poruszenie związane $\mathrm{z}$ tą tragedią jako argument na rzecz produkcji Godzilli, a Honda - jak wynika ze wspomnień jego bliskich - na wieść o tym wydarzeniu przeżył wstrząs, twórcy filmu obeszli się z tematem delikatnie, wprowadzając jedynie drobne nawiązania do niego, w rodzaju uwypuklenia śmierci operatora radiowego pierwszego ze statków zaatakowanych przez monstrum (odniesienie do postaci Aikichiego Kuboyamy) czy sceny przedstawiającej puste sieci rybaków z Odo (odniesienie do branży, w której pracowała załoga statku, i bojkotu tuńczyka). Początkowo Honda miał zamiar bezpośrednio połączyć historie „Szczęśliwego smoka nr 5” i Godzilli, za sprawą ewokującej Nosferatu - Symfonię grozy (Nosferatu, eine Symphonie des Grauens, 1922) sekwencji otwierającej, ukazującej pozbawiony życia statek wolno wpływający do portu $^{51}$. Podczas prac nad scenariuszem uznal jednak, że temat jest jeszcze zbyt drażliwy, by mówić o nim otarcie, zwłaszcza na gruncie kina gatunkowego. „Uniknęliśmy otwartego podjęcia tej kwestii, ponieważ uznaliśmy, że umieszczanie autentycznego wypadku w fikcyjnej opowieści, w centrum której znajduje się potwór, byłoby nie na miejscu" ${ }^{2}$ - stwierdził Honda. W pięć lat po premierze Godzilli na ekrany japońskich kin trafił film w całości poświęcony tragedii statku: Szczęśliwy smok nr 5 (Daigo Fukuryū Maru, 1959) w reżyserii Kaneto Shindō.

Część charakterystyki, jaką w zarysie historii Kayama obdarzył dr Yamane, została $\mathrm{w}$ filmie przeniesiona na dr Serizawę, który w pierwotnej koncepcji był postacią drugoplanową. W bohaterze tym nietrudno doszukać się reprezentacji zarówno samego Ishirō Hondy, jak i wielu jego rówieśników, którzy z wielkiej „świętej wojny” wrócili pozbawieni złudzeń, za to z dotkliwymi ranami na ciele i duszy. Emiko (Momoko Kōchi), córka dr Yamane stwierdza w jednej ze scen: „Ciężko mi, kiedy myślę o Serizawie. Gdyby nie wojna, nie miałby tak straszliwej blizny”. Serizawa jest przedstawicielem pokolenia, które nie tylko przegrało wojnę, ale i straciło wiarę jeśli już nie w ludzkość, to przynajmniej w jej

50 I. Yomota, The Menace from the South Seas: Honda Ishirō's Godzlla (1954), [w:] Japanese Cinema: Texts and Contexts, red. A. Phillips, J. Stringer, Oxon \& New York 2007, s. 105.

${ }^{51}$ D Kalat, op. cit., s. 33.

52 S. Galbraith IV, Monsters Are Attacking Tokyo!: The Incredible World of Japanese Fantasy Films, Port Townsend 1998, s. 23. 
przywódców, którzy pchnęli ją w odmęty konfliktu totalnego. Powodem, dla którego Serizawa nie chce użyć swego wynalazku, nie jest bynajmniej bliżej nieokreślone „widzi-mi-się", do jakiego przyzwyczaiła odbiorców pulpowa fantastyka. Źródła jego postawy są skonkretyzowane i oparte na racjonalnych przesłankach: obawia się, że upublicznienie „Niszczyciela Tlenu” otworzy kolejny etap wyścigu zbrojeń, w którym już teraz „bomby atomowe stawia się naprzeciw bomb atomowych” a „bomby wodorowe naprzeciw bomb wodorowych".

Serizawa nie może znaleźć wspólnego języka z młodszym Ogatą (Akira Takarada) nalegającym na wykorzystanie niebezpiecznej technologii $\mathrm{w}$ walce $\mathrm{z}$ monstrum - symbolizującym pokolenie, w pamięci którego obrazy grozy wojny uległy zamazaniu. Po części to właśnie do nich Honda skierował swoje dzieło. „Wielu młodych widzów [Godzilli] albo w ogóle nie posiadało o wojnie wiedzy z pierwszej ręki, albo miało tylko jej mgliste wspomnienia" ${ }^{33}$ - stwierdził po latach. Godzilla jest w pewnym sensie popkulturowym traktatem o pamięci i konieczności jej pielęgnowania. Należy zachować pamięć o zbrodniach wojennych i ich ofiarach, by podobne przypadki nie wystąpiły w przyszłości. W kontekście tym niezwykle wymowna jest scena rozgrywająca się na wyspie Odo, w której starzec stwierdza, że za ataki na statki odpowiedzialna jest mityczna Godzilla. Młoda kobieta wyśmiewa go, mówiąc, że zarówno on, jak i Godzilla są reliktami przeszłości. Ten zaś odpowiada: „Co ty możesz wiedzieć o starych czasach? Jeśli wszyscy będziecie tak myśleć, staniecie się łupem Godzilli”. Pamięć o wojnie i związanej z nią cierpieniami musi zostać utrzymana, jeżeli nie chcemy, by kolejny raz przetoczyła się przez glob.

Najważniejszym z autobiograficznych aspektów Godzilli nie są jednak ani filmowe manifestacje wspomnień reżysera z okresu wojny, ani tropy - mniej lub bardziej zawoalowane - umożliwiające identyfikację traumatycznych wydarzeń, które odcisnęły piętno na jego osobowości, lecz bijący z ekranu światopogląd reżysera, jego osobiste antyatomowe i pacyfistyczne posłannictwo. „Proszę wierzyć lub nie, ale w swej naiwności mieliśmy nadzieję, że koniec Godzilli zbiegnie się z zakończeniem testów nuklearnych" ${ }^{54}$ - stwierdził Honda. Reżyser zdołał swym zapałem zarazić resztę ekipy. Akira Takarada takimi słowy wspomina rozmowy, które podczas przerw obiadowych toczył na planie z Ishirō Hondą, Tomoyukim Tanaką , Takashim Shimurą, Momoko Kōchi i Akihiko Hiratą:

W tej harmonijnej i szczęśliwej atmosferze, nasze rozmowy w sposób naturalny zmierzały w kierunku bieżących wydarzeń i tła społecznego, w szczególności zniszczeń spowodowanych testami bomb atomowych i wodorowych oraz tragicznego losu „Szczęśliwego smoka nr 5”. Rozmowy ciągnęły się dalej w kierunku [konstatacji, że] z racji tego, iż Japonia była pierwszym krajem, na który zrzucono bombę atomową, powinniśmy zawrzeć w naszym filmie ostrzeżenie dla świata, starać się wyprzedzić tę szybko rozwijającą się gałąź nauki ${ }^{55}$.

Antyatomowe przesłanie Godzilli zostało otwarcie zwerbalizowane w wieńczącej film wypowiedzi dr Yamane: „Nie mogę uwierzyć w to, że Godzilla był jedynym ocalałym przedstawicielem swego gatunku. Jeżeli nadal będziemy przeprowadzać testy nuklearne, możliwe

53 S. Ryfle, op. cit., s. 37.

${ }^{54}$ W. M. Tsutsui, Kaiju Eiga, s. 208.

55 A. Takarada, Most Sincere Director, online: http://www.japanesegiants.com/honda/messages/m00001/ m000002_takarada.shtml [stan na dzień 10.04.2012]. 
jest, że gdzieś na świecie pojawi się kolejny Godzilla”. Honda był idealistą, być może naiwnym, lecz szczerym, wierzącym w to, że jego film zostanie odebrany jako ważny głos w debacie nad atomowym wyścigiem zbrojeń. Po latach stwierdzil, że najbardziej zabolała go recenzja, w której film nazwano groteskowym śmieciem i prymitywną próbą kapitalizacji na japońskich koszmarach nuklearnych ${ }^{56}$. Nigdy nie stracił nadziei na to, że świat uwolni się od widma atomowego zagrożenia:

Mówi się, że ilość bomb atomowych nie zmniejszyła się od 1954 roku ani o jedną. Domagamy się odrzucenia broni nuklearnej zarówno po stronie Amerykanów, jak i Rosjan. W tym tkwią właśnie korzenie Godzilli. Niezależnie od tego, jak wiele filmów o Godzilli zostanie wyprodukowanych, nigdy nie będzie ich za wiele ${ }^{57}$.

W późniejszych produkcjach spod znaku tokusatsu Honda niejednokrotnie powracał do frapującej go problematyki. Na poziom ideologicznego zaangażowania Godzilli i wyżyny artyzmu możliwego do osiągnięcia w ramach konwencji reżyser wzniósł się jednak już tylko raz. Matango (1963), kameralny dramat science-fiction, luźno oparty na opowiadaniu Nocny głos (The Voice in the Night) Williama Hope'a Hodgsona, nie tylko po raz kolejny przestrzegał przed niebezpieczeństwami „Ery Atomu”, ale i snuł alegoryczną refleksję nad losem tzw. hibakusha 被爆者 (dosł. „ludzie dotknięci eksplozją”), osób, które przeżyły wybuch bomby atomowej i cierpią na związane z nią dolegliwości. Wątki atomowe stopniowo odgrywały w filmach Hondy coraz mniej istotną rolę, funkcjonując zazwyczaj na zasadzie pretekstu do inicjacji fantastycznej fabuły. O ile ich obecność w Mysterianach (Chikyū bōeigun, 1957) - w których przedstawiciele pozaziemskiej cywilizacji, próbującej dokonać inwazji na Ziemię, cierpią na zaburzenia genetyczne spowodowane wojną nuklearną na ich rodzimej planecie - posiada jeszcze pewną nośność znaczeniową, o tyle wprowadzenie ich do filmu Frankenstein kontra Baragon, świadczyć może już wyłącznie o fiksacji reżysera.

\section{Bestia odpolityczniona: amerykanizacja Godzilli}

Starania Ishirō Hondy, by Godzilla wykraczał poza formułę standardowego atomowego monster movie, zostały zaprzepaszczone przez amerykańskich dystrybutorów filmu. Trudno zgodzić się z opinią Jerome’a Franklina Shapiro, według którego: „choć znacznie zmieniony, film z 1956 roku pozostaje wierny duchowi oryginału [... ], a jeżeli już, to czyni pewne rzeczy jeszcze bardziej oczywistymi dla amerykańskiej widowni" ${ }^{8}$. Faktem jest, że w Stanach Zjednoczonych i Kanadzie wyświetlano półprodukt, pozbawiony większości odniesień do bomby atomowej oraz wojny. Usunięto m.in. sceny ewakuacji ludności cywilnej i uwagę

Emiko o „bliznach” dr Serizawy. Zmieniono również powody, dla których dr Serizawa nie

\footnotetext{
56 S. Ryfle, op. cit., s. 37.

57 Ibidem, s. 44.

58 J. F. Shapiro, Atomic Bomb Cinema: The Apocalyptic Imagination on Film, London-New York 2002, s. 112.
} 
chce użyć „Niszczyciela Tlenu”. W Godzilli: Królu potworów nie obawia się on inicjacji nowego wyścigu zbrojeń, lecz tego, że jego wynalazek wpadnie w niepowołane ręce. Film legitymizuje tym samym posiadanie broni atomowej przez „dobrych chłopaków”, jednocześnie odmawiając tego prawa - by zacytować Ronalda Reagana - „imperium zła”. Największa zmiana wprowadzona przez dystrybutorów dotyczy jednak wypowiedzi zamykającej film, za sprawą której zmieniono jego antyatomową wymowę. O ile w oryginale dr Yamane wyraża głęboki niepokój o przyszłość ludzkości, jeżeli ta będzie kontynuować eksperymenty nuklearne, o tyle w amerykańskiej wersji Steve Martin (sic!), reporter grany przez Raymonda Burra, stwierdza: „Zagrożenie minęło. Zginął również wspaniały człowiek. Świat jednak mógł się przebudzić i wrócić do życia”.

Wśród historyków nurtu kaijū eiga do dziś brakuje zgody, co do przyczyn wprowadzenia przez dystrybutorów tak dalece posuniętych zmian. Dominuje pogląd wedle którego ci byli zmieszani ledwie tylko zawoalowaną antyamerykańską wymową filmu, dlatego zdecydowali się na wycięcie fragmentów o wymowie politycznej ${ }^{59}$. Wskazuje się również na to, że Levine był świadomy tego, iż fabuła Godzilli opierała się na autentycznych wydarzeniach i że w istocie był to film polityczny, który nie mógł zostać zaprezentowany amerykańskiej widowni w swej oryginalnej postaci ${ }^{60}$. Dystrybutorzy jednak bronili się przed tego rodzaju oskarżeniami. Richard Kay stwierdził niegdyś:

Nie. Proszę mi wierzyć - nie byliśmy zainteresowani polityką. Chcieliśmy tylko stworzyć film, który by się sprzedał. W tamtym okresie amerykańska widownia nie wybrałaby się do kina na film z wyłącznie japońską obsadą. To dlatego zrobiliśmy to, co zrobiliśmy. Nie poczyniliśmy drastycznych zmian w historii. Po prostu nadaliśmy jej amerykański punkt widzenia ${ }^{61}$.

Choć zmianę wymowy filmu - która, wbrew opinii Kaya, wystąpiła - trudno uznać za dzieło przypadku, wersję dystrybutorów zdaje się potwierdzać fakt, że z amerykańskiej wersji usunięto nie tylko wątki odnoszące się do bomby atomowej i wojny, ale również sceny kreślące rys osobowościowy poszczególnych bohaterów oraz precyzujące relacje między nimi (m.in. wczesną scenę identyfikującą Emmiko i Ogatę jako parę). Jakiekolwiek byłyby jednak intencje dystrybutorów, faktem pozostaje, że Godzilla: Król potworów nie jest celuloidowym traktatem o broni nuklearnej, jakim było dzieło Hondy. Niemal w pełni - jeśli abstrahować od miejsca akcji i japońskiej obsady - wpisuje się za to w nurt atomowego science-fiction spod znaku To przybyło z głębin morza czy Bestii z głębokościa 20.000 sążni, $\mathrm{w}$ których remedium na atomowe zagrożenie jest posiadanie silniejszej broni, niezależnie od tego, czy będą to torpedy z głowicą nuklearną, pociski zawierające izotop radioaktywny, czy „Niszczyciel Tlenu”. Choć w kolejnych dekadach w amerykańskich kinach roznosił się ryk Godzilli i jego pobratymców, głos Ishiro Hondy dał się posłyszeć tam dopiero w 1982 roku.

\footnotetext{
${ }^{59}$ W. M. Tsutsui, Kaiju Eiga, s. 208.

60 S. L. Allsop, op. cit., s. 64.

${ }^{61}$ S. Ryfle, op. cit., s. 57-58.
} 


\section{Postscriptum}

Podobnie jak w przypadku zachodniego kina science-fiction, przeważająca większość filmów z nurtu tokusatsu miała służyć jedynie rozrywce. Choć na ekranach kin gościły zaangażowane potwory (m.in. proekologiczna Mothra), japońska fantastyka filmowa rzadko za swój nadrzędny cel stawiała sobie edukację i agitację. Mimo to, nawet w swoim najbardziej rozrywkowym wydaniu, filmy spod znaku tokusatsu stanowią wartościowe dokumenty społeczne i źródło poznania nastrojów społecznych oraz niepokojów, charakterystycznych dla poszczególnych dekad historii Japonii.

Kino popularne może istnieć tylko wtedy, jeśli utrzymuje żywy kontakt ze społeczeństwem, wtapia się w jego tkankę i płynie w jego krwiobiegu. Musi więc opisywać świat widza, odnosić się do jego doświadczeń i problemów, nawet jeżeli czyni to w sposób pośredni, przefiltrowany przez wyobraźnię twórców i konwencje gatunkowe: gdy bomba atomowa przyjmuje postać Godzilli, zanieczyszczenie środowiska - Hedory, komunizm - najeźdźców z obcej planety... 